\title{
Successful Treatment of Infective Endocarditis Vegetation with Recombinant Tissue Plasminogen Activator in a Term Newborn
}

\author{
Term Bir Yenidoğanda Rekombinan Doku Plazminojen Aktivatörü ile Başarı ile Tedavi Edilen İnfektif Endokardit \\ Olgusu
}

\author{
Erbu Yarci ${ }^{1}$, Fatma Nur Sari ${ }^{1}$, Aslihan Kose Cetinkaya ${ }^{1}$, Handan Asilhan Unsal ${ }^{2}$, Evrim Alyamac Dizdar ${ }^{1}$ \\ Hayriye Gözde Kanmaz Kutman ${ }^{1}$, Serife Suna Oguz ${ }^{1}$
}

${ }^{1}$ Division of Neonatology, Zekai Tahir Burak Women's Health Training and Research Hospital, Faculty of Medicine, University of Health Sciences, Ankara, Turkey 2Division of Pediatric Cardiology, Zekai Tahir Burak Women's Health Training and Research Hospital, Faculty of Medicine, University of Health Sciences, Ankara, Turkey

\begin{abstract}
The development of infective endocarditis and cardiac thrombus is a rare but serious complication in the newborn infant. Herein we report the use of recombinant tissue plasminogen activator in a term infant to successfully treat a Staphylococcal infective endocarditis vegetation that was unresponsive to antimicrobial therapy and not amenable to surgical therapy.
\end{abstract}

Key Words: Newborn, thrombocytopenia, infective endocarditis, S. aureus, vegetation, thrombolytic treatment

Received: 12.06 .2017

Accepted: 03.03.2018

\section{ÖZET}

Yenidoğanda enfektif endokardit ve kardiyak tromboz gelişimi, nadir ancak ciddi bir komplikasyondur. Burada rekombinan doku plazminojen aktivatörü kullanılarak başarı ile tedavi edilen antimikrobiyal tedaviye yanıt vermeyen ve cerrahi tedaviye uygun olmayan bir Stafilokokkal infektif endokardit olgusu sunulmuştur.

Anahtar Sözcükler: Yenidoğan, trombositopeni, infektif endokardit, S. aureus, vejetasyon, trombolitik tedavi

Geliş Tarihi: 06.12.2017

Kabul Tarihi: 03.03.2018

\section{INTRODUCTION}

The development of infective endocarditis and cardiac thrombus is a rare but serious complication in the newborn infant(1). Infective endocarditis in the absence of congenital heart disease is often associated with indwelling venous catheters(2). Conventional management of infective endocarditis involves removal of the infected indwelling catheter and prolonged treatment with anti-infective agents to eliminate the invading organism harbored within the vegetations $(2,3)$. In the presence of persistant positive blood cultures despite conventional medical regimens, surgical intervention is indicated to remove the infected vegetations.

Herein we report the use of r-TPA in a term infant to successfully treat a Staphylococcal infective endocarditis vegetation that was unresponsive to antimicrobial therapy and not amenable to surgical therapy.

\section{CASE REPORT}

A 39-week gestation male infant, with a birth weight of $3410 \mathrm{~g}$, was delivered by caesarian section, with APGAR scores of 8 at 1 min and 10 at 5 $\min$. The infant was breast-fed for the first day. On day 2 , he was found to be hypoglycemic and hospitalized to newborn intensive care unit and umbilical venous catheter was placed with ampiric use of penicillin $\mathrm{G}$ and gentamicin therapy. On day 6 the infant had recurrent apnea, bradycardia, hypercarbia requiring ventilatory support and laboratory evaluations hyperglycemia, anemia, leucocytosis $\left(33 \times 10^{9} / \mathrm{L}\right)$, thrombocytopenia $\left(17 \times 10^{9} / \mathrm{L}\right)$. He also had elevated levels of CRP and IL-6. Late onset sepsis was suspected and following septic screening antibiotics (vancomycin and amikacin) were commenced. The blood culture subsequently grew Staphylococcus aureus. The infant was tachycardic and had a grade 2 systolic murmur.

Address for Correspondence/ Yazışma Adresi: Erbu Yarci, MD Division of Neonatology, Zekai Tahir Burak Women's Health Training and Research Hospital, Faculty of Medicine, University of Health Sciences, Ankara, 06230, Turkey E-mail: erbuyarci@yahoo.com

CTelif Hakkı 2018 Gazi Üniversitesi Tıp Fakültesi - Makale metnine http://medicaljournal.gazi.edu.tr/ web adresinden ulaşılabilir. (C) Copyright 2018 by Gazi University Medical Faculty - Available on-line at web site http://medicaljournal.gazi.edu.tr/

doi:http://dx.doi.org/10.12996/gmj.2018.41 
On day 7 , echocardiography demonstrated a vegetation measuring $8 \mathrm{~mm}$ by 7 $\mathrm{mm}$ on the right atrium related to atrial septum(Figure $1 \mathrm{~A})$. The umbilical venous catheter was removed and conservative treatment was continued. On day 10 repeat echocardiography revealed that the vegetation had increased in size to $13 \mathrm{~mm}$ by $14 \mathrm{~mm}$ and was highly mobile(Figure 1B). Based on increasing size of vegetation, persistent thrombocytopenia, treatment with recombinant tissue plasminogen activator( $r$-TPA) was considered. A central catheter was reinserted for the administration of $r$-TPA.
Cranial ultrasound was normal and performed daily, coagulation studies(protrombin time, activated partial thromboplastin time) were performed and fibrinogen levels were measured before initiating therapy and daily thereafter. The infant received intravenous fresh frozen plasma (10 $\mathrm{mL} / \mathrm{kg}$ ) before $\mathrm{r}$-TPA infusion to maintain fibrinogen level $>100 \mathrm{mg} / \mathrm{dL}$ and platelet infusions as required to maintain platelet count above $100 \times 10^{9} / \mathrm{L}$. An initial dose of $0.2 \mathrm{mg} / \mathrm{kg} / \mathrm{hr}$ was given by continuous infusion over 6 hours for 8 days until the vegetation was no longer visualized by echocardiography(Figure 1C). Anticoagulant therapy was continued with low molecular weight heparin for 12 weeks. The infant made a full recovery and received antibiotic treatment for 6 weeks repeated echocardiography revealed normal heart function.

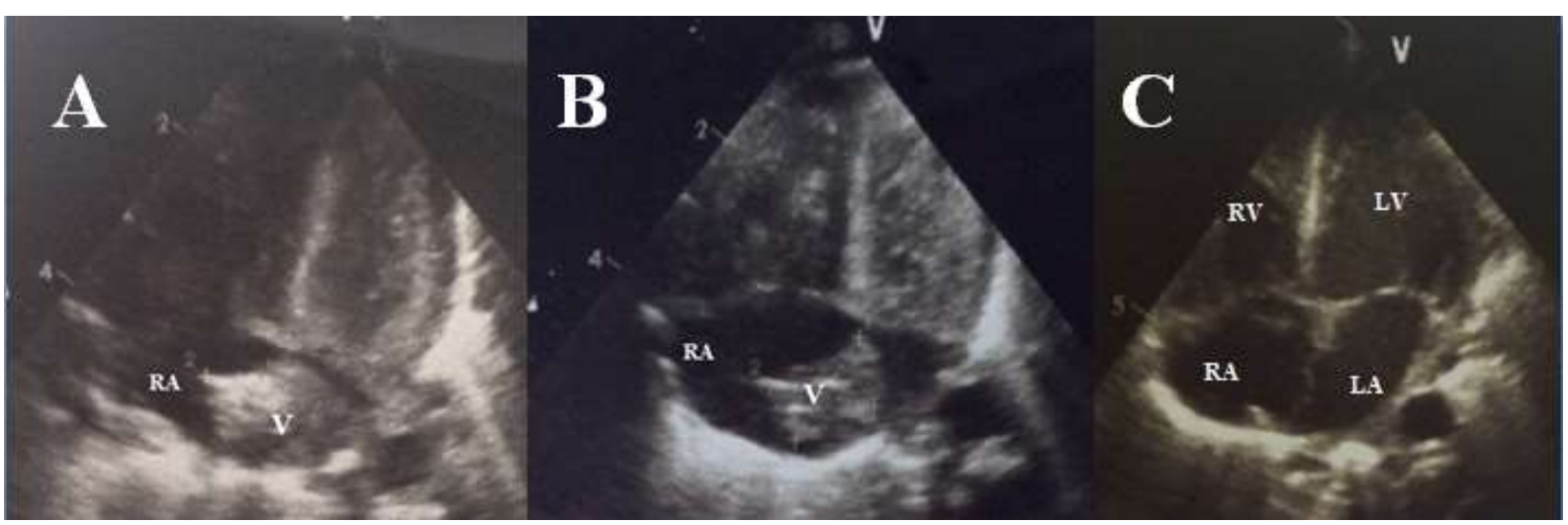

Figure 1. A, Transthoracic echocardiogram showing right atrial trombus on day $7(8 \times 7 \mathrm{~mm})$. B, Transthoracic echocardiogram showing enlarged right atrial trombus on day $10(13 \times 14)$. C, Normal echocardiogram at the end of eight days of recombinant tissue plasminogen activator therapy on day 18 . LA, left atrium; LV, left ventricle; $\mathbf{R A}$, right atrium; RV, right ventricle; $\mathbf{V}$,vegetation

\section{DISCUSSION}

Despite current treatment options IE remains a serious problem with mortality rates $25 \%-33 \%$ for neonates, $11 \%$ for children. Surgical intervention has been reported in $31 \%$ to $76 \%$ of pediatric patients with infective endocarditis often for resection of the vegetation alone(4).

In bacterial infective endocarditis, intravenous bactericidal antibiotics should be used, and a prolonged course of therapy is necessary(5). Failure to respond to medical therapy with vegetations increasing in size, persistent positive blood cultures, risk of systemic emboli, and progressive heart failure are all indications for surgical intervention(6). As surgical management for intracardiac thrombi in neonates is associated with high mortality medical management is preferred, and may be the only feasible modality of treatment(7).

In our patient, positive blood cultures, severe thrombocytopenia, and enlarging vegetation were indications for treatment with r-TPA. Complications of r-TPA treatment have been described in the literature. Oozing from puncture sites, hematuria, and blood-tinged tracheal aspirates are most frequently reported(8). Nowak-Goth et al. reported major complications such as pulmonary bleeding, gastrointestinal bleeding, intraventriculer hemorrhage and two deaths directly related to massive hemorrhage(9). No adverse effects attributed to r-TPA were observed in our patient during the treatment course.

In conclusion, the successful use of r-TPA in our patient and also in cases previously reported suggest that r-TPA should be considered in the setting of infective endocarditis related to central venous catheterization and/or systemic bacterial infection unresponsive to antimicrobial therapy.

\section{Conflict of interest}

No conflict of interest was declared by the authors.

\section{REFERENCES}

1. Anderson B, Urs $P$, Tudehope $D$, Ward $C$. The use of recombinant tissue plasminogen activator in the management of infective intracardiac thrombi in pre-term infants with thrombocytopaenia. Journal of Paediatrics and Child Health 2009;45:598-601.

2. Saiman L, Prince A, Gersony WM. Pediatric infective endocarditis in the modern era. J Pediatr 1993;122:847-53.

3. Stull TL, Lipuma JJ. (1992) Endocarditis in children. In: Kaye D (ed). Infective endocarditis. 2nd ed. New York, Raven Press, p.313-27.

4. Fleming RE, Barenkamp SJ, Jureidini SB. Successful treatment of a Staphylococcal endocarditis vegetation with tissue plasminogen activator. J. Pediatr. 1998; 132: 535-7.

5. Dajami AS, Taubert KA. (2001) Infected endocarditis in: Moss AJ, Adams FH, editors. Heart disease in infants, children and adolescents. 6th ed, vol 2. Philadelphia (PA): Lippincott Williams \& Wilkins;. p.1297-1308.

6. Douglas JL, Dismukes WE. (1992) Surgical therapy of infective endocarditis on natural valves. In: Kaye D (ed). Infective endocarditis. 2nd ed. New York (NY): Raven Press; p. 397.

7. Nomura F, Penny DJ. Surgical intervention for infective endocarditis in infancy and childhood. Ann. Thorac. Surg. 1995; 60: 90-5.

8. Leaker M, Massicotte P, Brokker LA, Andrew M. Thrombolytic therapy in pediatric patients: a comprehensive review of the literature. Thromb Haemost 1996;76:132-4.

9. Nowak-Goth U, Auberger $\mathrm{K}$, Halimeh S. Thrombolysis in newborns and infants. Thromb. Haemost. 1999; 82: 112-6. 